University of Michigan Law School

University of Michigan Law School Scholarship Repository

Law \& Economics Working Papers

3-2-2021

\title{
Reforming Michigan Vehicle Direct Sales Laws
}

Daniel A. Crane

University of Michigan Law School, dancrane@umich.edu

Follow this and additional works at: https://repository.law.umich.edu/law_econ_current

Digitadrt of the Law and Economics Commons, and the Public Law and Legal Theory Commons

Commons

\section{Network}

Working Paper Citation

Crane, Daniel A., "Reforming Michigan Vehicle Direct Sales Laws" (2021). Law \& Economics Working

Papers. 177.

https://repository.law.umich.edu/law_econ_current/177

This Article is brought to you for free and open access by University of Michigan Law School Scholarship Repository. It has been accepted for inclusion in Law \& Economics Working Papers by an authorized administrator of University of Michigan Law School Scholarship Repository. For more information, please contact mlaw.repository@umich.edu. 
Crane:

\title{
Reforming Michigan VeHICle Direct SAles LAWS
}

\author{
Daniel A. Crane* \\ Frederick Paul Furth, Sr. Professor of Law \\ University of Michigan
}

March 2, 2021

\footnotetext{
${ }^{*}$ This white paper is presented solely in my academic capacity, represents solely my own views, and does not represent the views of the University of Michigan or any other organization with which I am affiliated. I have received no compensation, directly or indirectly, from any company or organization for the preparation of this white paper, nor do I work for any company or organization with a direct interest in the outcome of the potential legislative reforms at issue.
} 


\section{EXECUTIVE SUMMARY}

Michigan stands at a crossroads with respect to the way that electrical vehicles ("EVs") are sold and serviced. For many decades, Michigan—like many other states—mandated that cars could be sold and serviced only through independent, franchised dealers and prohibited car manufacturers from selling or servicing directly. Historically, those laws were put in place to protect dealers from the superior bargaining power, and sometimes unfair practices, of the Big Three car companies - General Motors (“GM”), Ford, and Chrysler.

With the advent of EV technology, it became clear that these decades-old restrictions on direct sales and servicing needed to be reconsidered. Tesla, the first large-scale EV company to market, made the case that direct sales and service were critical to EV market penetration and the success of its business model. From about 2014 forward, many states began to loosen their prohibitions on direct distribution to allow Tesla to operate. Michigan, however, went in the opposite direction. A 2014 amendment to the Motor Vehicle Franchise Act ("MVFA"), passed under questionable circumstances, was intended to shut the door on any possibility that Tesla could engage in direct sales or service in Michigan. While many other states were moving forward, Michigan moved back.

Tesla filed a constitutional challenge to the 2014 amendment in federal court in the Western District of Michigan. The court made clear that it would allow the case to proceed to trial. In early 2020, Attorney General Nessel announced a settlement with Tesla that interpreted the State's dealer law to permit Tesla to engage in any aspect of marketing a vehicle-opening showrooms, giving test drives, receiving trade-ins, setting up the sales transaction—so long as the actual sales transaction was orchestrated out of state. It also interpreted the Michigan statute to permit Tesla to open service centers, so long as it did so through a subsidiary. In effect, this 
interpretation of Michigan law allowed Tesla to sell and service its cars in Michigan, subject to jumping a few formal hurdles.

By 2020, the EV sales issue was not just Tesla's. Not only were most of the legacy car companies beginning to roll out EVs, but a host of new EV start-ups-Rivian, Lordstown, Lucid, Bollinger, Nikola, and others-were preparing to reach the market. These new EV startups join Tesla in arguing urgently for the need to sell and service their vehicles directly in order to achieve critical mass and insist that traditional dealer distribution will not work for their business model. Because they are similarly situated to Tesla, at present these companies can arguably take advantage of the Tesla settlement and operate in Michigan as Tesla does.

Unfortunately, the car dealers' lobby — which was behind the 2014 legislation —is unhappy with any prospect of direct sales. In the fall of 2020, the dealers pushed a bill-H.B. 6233 - in the Michigan legislature to "close the Tesla loophole." The original version of the bill, passed in committee, would have preserved the Tesla settlement, but prohibited other EV start-ups from direct sales and service. The version of the bill changed through floor amendment and that ultimately passed in the House went even further-it eviscerated the Tesla settlement and denied direct sales or service to any car company, including Tesla. Fortunately, the Senate did not take up the bill, and it died with the last legislative session.

It's time for Michigan to adopt reform legislation to bring clarity to the question of EV sales and to permit car companies to reach their customers directly. The rationales for such reforms are many, and include:

(1) EV market penetration: For a variety of reasons, the traditional dealer model is ill-suited to EV sales and service. Therefore, mandating EV sales and service 
through dealers will slow EVs' market penetration and prevent the growth of the EV sector.

(2) Environmental impact: Slowing EV market penetration means more internal combustion vehicles on the road and more carbon emissions. A coalition of environmental and electrification organizations including the Sierra Club, Environmental Council, Electrification Coalition, Ecology Center, E2, Plugin America, and Cleanfuels Michigan have prioritized direct sales reforms for this reason.

(3) Consumer choice and consumer protection: A host of consumer protection organizations, including the staff of the U.S. Federal Trade Commissions, the Consumer Federation of America, and Consumer Action, Consumers for Auto Reliability and Safety, and the American Antitrust Institute have argued that prohibitions on direct vehicle sales are bad for car buyers, consumer choice, and competition.

(4) Threats to the free market: Restrictions on direct distribution tell a car manufacturer that it may not sell its own products to willing buyers, and tell consumers that they cannot choose how to buy a car. Free market organizations like the Mackinac Center, Americans for Prosperity, and the Institute for Justice have argued against these laws on the grounds that they unjustifiably interfere with free markets and represent government regulation favoring special interests.

(5) Economic impacts for the State of Michigan: The current system - in which EV start-ups can sell cars directly to Michigan residents so long as they perform the 
sales transaction out of state—represents a potentially enormous economic cost to the State. Lost sales, property, and other taxes may soon run into the hundreds of millions of dollars. This scheme will also discourage investment and employment in the state, and send a negative signal about Michigan's openness to automotive innovation and investment.

The case for legislative reform is clear. This White Paper concludes by presenting two reform options - allowing direct sales and service by EV start-ups, or allowing direct sales and service for any company selling EVs — and argues that the second option is fairer and more workable.

\section{BACKGROUND}

1. Historical Background on Vehicle Direct Sales Prohibitions

Most Americans would be surprised to learn that there is an important sector of the economy in which some states' laws prohibit a company from selling its own products to consumers or providing after-market service for those products. We are used to buying iPhones from Apple, basketball shoes from Nike, cable services from Comcast, and houses from the builders who make them. But, for many decades, car manufacturers have been subject to prohibitions on selling their cars directly to consumers, or servicing them in the aftermarket. Instead, many states' laws require manufacturers to sell and service through independent franchised dealers.

How did this come about? In the early years, of internal combustion vehicles, car manufacturers used a wide variety of distribution methods, including dealer franchising, traveling salesmen, consignment, direct sales through company-owned stores, and sales through general 
retailers. ${ }^{1}$ Historically, there is nothing inevitable about dealer distribution as the exclusive means of getting cars to customers. The present dealer-franchise system arose during the period between 1930 and 1950. At that time, the Big Three dominated car sales and dealers were mostly "mom and pop" local businesses. The dealers complained that the Big Three took unfair advantage of their unequal bargaining power to impose draconian contractual terms on the dealers. For example, Henry Ford allegedly forced dealers to buy Model Ts that they could not sell under threat of not getting any more inventory. The dealers also argued that the Big Three unfairly competed against their own franchised dealers by offering lower prices at company-owned stores than independent dealers could match.

The dealers ultimately persuaded most state legislatures to pass laws regulating the automobile dealership relationship to protect the dealers (not consumers). Among the provisions of most of these laws was a prohibition on the manufacturer opening its own showrooms and service centers and thereby undermining its franchised dealers. Those direct distribution prohibitions have mostly carried over until the last decade, when some states began to loosen them in light of the changing economic, technological, and social landscape.

Even before coming to the novel distribution issues raised by EVs, it had become clear in recent decades that the original dealer protection rationales for the direct distribution prohibitions were waning. As noted, the dealers' arguments for protection from the manufacturers were based on two economic facts creating grossly unequal bargaining power: (1) car manufacturing was a three-firm oligopoly with little competition among the Big Three on franchising terms; and (2) car dealers were local, family-owned, mom and pop combinations. The

\footnotetext{
${ }^{1}$ The historical information presented here is taken from Daniel A. Crane, Tesla, Dealer Franchise Laws, and the Politics of Crony Capitalism, 101 Iowa L. Rev. 573 (2016), available at https://repository.law.umich.edu/cgi/viewcontent.cgi?article=2720\&context=articles.
} 
world is radically different today. First, there has been considerable new entry from foreign competitors, making the car market much, much more competitive than it was in the mid-twentieth century. Car dealerships can now negotiate with around fifteen to twenty different car manufacturers over potential dealership opportunities. Second, many car dealerships are no longer mom and pops, but part of multi-billion dollar dealer groups. The Top 10 dealership groups in America have annual revenues around $\$ 100$ billion—more than any car company. ${ }^{2}$ To put things in perspective, that's about one-fifth of Michigan's GDP. Many of these large dealer groups operate in Michigan. For example, the Suburban Collection based in Troy operates 47 dealerships in Michigan and reported \$2.6 billion in revenue in 2019. ${ }^{3}$ Based on these economic changes, it would be hard to argue that the inequality of bargaining power between manufacturers and dealers is anything like what it was in the mid-twentieth century.

2. Tesla's Entry—Nationwide Responses

When Tesla entered the market in 2013, it announced that it would be selling and servicing its vehicles directly, and not employing franchised dealers at all. A customer buying a Tesla buys the car directly from Tesla and has the vehicle serviced by Tesla. In testimony before the Federal Trade Commission, Tesla explained that seven factors supported its rationale: ${ }^{4}$

1) Dealership locations: Dealerships are usually found in out-of-the way locations. Tesla feels it's important to "bring the new technology to the consumer" in places like shopping malls.

\footnotetext{
${ }^{2}$ https://s3-prod.autonews.com/data-protected/032519-2019Top150DealershipGroups032519.pdf?djoDirectDownload=true.

${ }^{3}$ Id.; see also https://papers.ssrn.com/sol3/papers.cfm?abstract_id $=3000497$.

${ }^{4} \mathrm{https}$ ://evannex.com/blogs/news/74602181-tesla-defends-direct-sales-model-at-ftc-talks-cites-unfair-oppositionfrom-gm.
} 
2) Inventory differences: Large inventory is the lifeblood of traditional dealerships, but Tesla works on a built-to-order model.

3) Longer sales cycles: The franchised dealer model is based on high volume of fast-paced sales. EV buyers take longer to educate themselves on EV sales, and therefore need to work with sales people who are working on a commission model.

4) Different profit models: Traditional dealerships earn low profit margins on new car sales, and make it up on service. EVs have a much smaller service component since they don't have service needs like oil changes or engine tuneups. Traditional dealerships therefore lack much of an incentive to sell EVs.

5) No advertising. Traditional dealerships rely on manufacturers to fund their advertising in TV, radio, and print media. Tesla does not advertise.

6) Dealer price mark ups. Franchised dealers could not make money selling Teslas, since they would have to mark them up, and therefore could not compete with Teslas sold directly from the company.

7) Conflict of interest. EV sales cannibalize internal combustion sales, which are the dealers' lifeblood. Dealers therefore lack the motivation to sell EVs.

Tesla's decision to sell direct and bypass dealers was not well-received by the car dealers. Beginning in 2014, the dealers launched a state-by-state battle to block Tesla's entry, arguing that direct sales and service were prohibited by existing law. Over the course of the next several years, these battles played out in state courts, motor vehicle commissions, and legislatures. In some cases, they are still ongoing. 
Today, almost half of the states have eased their direct sales restrictions for EVs. This has come about in several ways. Some states have held their existing dealer laws inapplicable to EV companies that do not want to use franchised dealers at all. For example, in holding that the dealers lack standing to challenge Tesla's entry, the Massachusetts Supreme Court held that is dealer franchise law was intended to protect dealers in franchise relationships with manufacturers, a circumstance inapplicable to Tesla that doesn't want to use franchised dealers at all. ${ }^{5}$ Similar interpretations have occurred in Minnesota, Missouri, Arizona, and Rhode Island. Other states like New Hampshire, Wyoming, Utah, and Colorado have passed new statutes opening the door to EV direct sales. Some states have allowed direct EV sales on a limited basis. For example, in 2014, the dealers and Tesla reached a compromise that allowed Tesla to open three stores in Ohio (that today are frequented by Michigan residents). Virginia, New Jersey, Maryland, Pennsylvania, New York, Georgia, and North Carolina similarly allow some direct EV sales. Finally, technologically important states like California have never blocked direct EV sales at all.

Even states that prohibit direct EV sales and service cannot stop their residents from buying EVs directly. Thus, in states like Michigan where direct EV sales have been prohibited until recently, thousands of Michigan residents still purchased Teslas. If they were willing to forego a test drive, they could buy the vehicle online and have it delivered. Or they could drive across the border into Ohio and purchase a Tesla from our friendly rivals to the south. Servicing has been more challenging. Since Tesla was, until recently, prohibited from opening a service center in Michigan, this meant that Michigan customers either had to wait for a service technician to come to their home or, again, drive to Ohio for service.

\footnotetext{
${ }^{5}$ Massachusetts State Auto Dealers Ass'n v. Tesla Motors MA, Inc., 469 Mass. 67, 515 N.E.3d 1152 (2014).
} 
Residents of every state are buying EVs directly and having them serviced directly.

The question is not whether that happens — it has, does, and will—but whether customers have the freedom and convenience of having that direct relationship with a manufacturer occur locally, or whether they to drive to another state. A critical mass of states-with the numbers growing every year — have decided to allow local sales and service.

\section{2014 Michigan Legislation}

Like most other states, Michigan has long prohibited direct sales and service, with the most recent version of its dealer protection statute dating back to $1977 .{ }^{6}$ However, until 2014, the statute was ambiguous as to whether it would apply to a company like Tesla that did not use franchised dealers at all. The statute provided that a manufacturer shall "[s]ell any new motor vehicle directly to a retail customer other than through its franchised dealers." ${ }^{\prime 7}$ The possessive its was potentially significant — the statute assumed that a manufacturer had franchised dealers. If, like Tesla, it did not, the Michigan courts might well have ruled the statute inapplicable.

In the fall of 2014, after the Massachusetts decision holding the Massachusetts statute inapplicable to Tesla, the Michigan car dealers' lobby became worried that the Michigan statute might be construed in the same way. They therefore pushed a floor amendment to an unrelated bill that struck the little word "its" from the statute. Many members of the Legislature from both sides of the aisle subsequently explained that they had no idea that this was intended to block Tesla — indeed, one member of the Legislature explained to me that he specifically asked, and was told, untruthfully, that the excision of "its" had nothing to do with Tesla or direct sales. Unfortunately, subsequent evidence would leave no doubt that this was the amendment's intent

\footnotetext{
${ }^{6} \mathrm{MICH}$. H. LEGIS. Analyis Section, SECOND ANALYSIS, H.B. 4738, 4740, at I ( 1-26-gg), http://www.legislature.mi.gov/documents/1997-1998/billanalysis/House/pdf/ 1997-HIA-4738- B.pdf.

${ }^{7}$ MICH. COMP. LAWS§445.1574(1) (i) (2013).
} 
and effect. Following the 2014 legislation signed by Governor Snyder, Michigan law unequivocally prohibited direct sales and service, effectively blocking Tesla from the State.

\section{Tesla Constitutional Challenge and Settlement}

At the time he signed the 2014 bill, Governor Snyder publicly stated that the issue of vehicle direct sales needed to be comprehensively studied and reconsidered. Unfortunately, after passing the anti-Tesla amendment, the Legislature never took up Governor Snyder's suggestion. In 2016, when it became clear that legislative reform was not forthcoming, Tesla filed a constitutional challenge to MDOS's 2015 denial of its application to operate a new vehicle dealership and a used vehicle dealership, and to register a repair facility, in the U.S. District Court for the Western District of Michigan. Tesla argued that this denial, occasioned by the 2014 legislative amendment, violated the equal protection clause of the Fourteenth Amendment and the "dormant" or negative commerce clause of Article I, Section 8 of the U.S. Constitution. Over the course of the next few years, discovery progressed in the case and, by 2020, the case was headed for trial.

On January 22, 2020, Attorney General Nessel announced a settlement with Tesla that essentially gave Tesla a full victory. ${ }^{8}$ As the Attorney General explained, "[t]he stipulation acknowledges that Tesla may: operate under existing Michigan law; sell cars to Michigan customers as long as the sales contract indicates the sale took place in a state other than Michigan; and, indirectly own service and repair facilities in Michigan through a subsidiary, Tesla Michigan.” The Attorney General achieved this result by interpreting existing Michigan law narrowly. M.C.L.

\footnotetext{
${ }^{8}$ https://www.michigan.gov/ag/0,4534,7-359-92297_92299-517800--,00.html.
} 
$\S 445.1574$, which prohibits manufacturers from owning service centers, does not apply to "indirect" ownership of a service center through a subsidiary. ${ }^{9}$ Further:

- No provision in M.C.L. $\S 445.1574(1)$ nor any other provision of Michigan law prohibits Tesla from delivering vehicles to Michigan residents in Michigan (whether directly, through a subsidiary, using an independent carrier, or otherwise), including assisting them with vehicle trade-ins, so long as legal title for any vehicles sold by Tesla transfers outside the state of Michigan, consistent with M.C.L. $§ \S 440.2106(1)$ and 440.2401; and

- Neither M.C.L. § 445.1574(1)(h) nor § 445.1574(1)(i) nor any other provision of Michigan law prohibits Tesla from operating one or more galleries in the State to educate customers and facilitate transactions out-of-state so long as Tesla does not transfer legal title to the vehicles within the State consistent with M.C.L. $\S \S 440.2106(1)$ and 440.2401. Permissible activities at such a gallery include (but are not limited to) conducting demonstration drives; discussing prices, service, financing, leasing, and trade-ins with potential customers; helping potential customers configure a vehicle; facilitating ordering and purchase of a vehicle for which legal title transfers out-of-state; and facilitating customer transaction paperwork for a sale for which legal title transfers out-of-state

Stripped of legalese, this settlement meant that Tesla was free to do every action associated with selling a car — offering test drives, quote prices and terms of sale, facilitating tradeins, configuring the vehicle, facilitating paperwork, and even delivering the car-in Michigan so long as the sale transaction and transfer of title technically occurs outside of the State. A customer can thus go to a Tesla gallery and do everything traditionally associated with the purchase of a car, then transact online to complete the sale with Tesla in California, and then take delivery of the car in Michigan.

5. The Failure of HB 6233 and Implications

The Tesla settlement wasn't a special deal for Tesla, which the Attorney General would not have had authority to make. Rather, it was a general interpretation of Michigan law. Under ordinary legal principles, any company situated like Tesla—which would include at least

\footnotetext{
${ }^{9} \mathrm{https}: / /$ www.michigan.gov/documents/ag/Joint_Stipulation_and_Motion_for_Entry_of_Dismissal_1-2220_679161_7.pdf.
} 
any EV manufacturer not distributing through franchised dealers - could take advantage of the same terms. The Tesla settlement thus opened the door for companies like Rivian, Lucid, Lordstown, Bollinger, and Nikola to sell and service in Michigan.

The car dealers' lobby was not happy about the prospect that the new generation of car companies would bypass them entirely. In September of 2020, the Michigan House Government Operations Committee took up a bill—H.B. 6233—proposed by the dealers to make sure that no EV company other than Tesla could take advantage of the settlement. The bill included a new and expansive definition of "sell" and "selling" that included virtually every activity associated with new vehicle sales transactions, including those that Tesla's settlement with the State recognize are not sales under the existing statute. It added the phrase "directly or indirectly" to the prohibition on manufacturer ownership of motor vehicle service and repair facilities, which would make it impossible for a new car manufacturer to do what the State agreed that Tesla can do-own a subsidiary performing service in Michigan. The bill would have shut down the possibility of interpreting Michigan law in the way the Attorney General interpreted it when settling with Tesla. In addition to making these substantive amendments to the existing statute, the Bill made clear that it applied to all manufacturers, all new dealer agreements, and all existing dealer agreements. But it then went on to make a special carve out for any "manufacturer that entered into a joint stipulation and motion for entry of dismissal" in the Tesla litigation and has not sold a single new motor vehicle in the state through a franchised dealer. Such entities could perform a list of enumerated activities, which corresponded directly to the activities that Tesla and the State agreed that Tesla could perform pursuant to the settlement. In other words, the bill doubled down on the existing restrictions on direct sales and service by manufacturers, but then enacts a single-company carve out to preserve the terms of Tesla's settlement with the State. 
The bill was vigorously opposed in Committee by EV start-ups like Rivian and Lucid, environmental groups like the Sierra Club and the Environmental Council, the Mackinac Center, GM, Ford, and the UAW. It nonetheless passed the Committee on a 3-1-1 party-line vote. H.B. 6233 was almost certainly unconstitutional under Article IV, Section 29 of the Michigan constitution, which prohibits "special acts" favoring a single company. ${ }^{10}$ But what happened next made things matters even worse: When the bill reached a floor vote on December 2, 2020, a floor amendment stripped out the Tesla exemption. This moved GM, Ford, and UAW to neutral on the bill (what they most opposed was carving a special exemption for Tesla into law), and provided enough political cover for the bill to pass in the House. But the bill now doubled down on making Michigan the most restrictive state in the Union on direct sales and service by broadly defining "sales" to include almost any activity an EV company might have taken in the State. Moreover, it blew up the Tesla settlement and would have barred even Tesla from Michigan sales and service. That, in turn, would have re-upped Tesla's original constitutional challenge, with the very real prospect that a federal court rather than the Legislature would determine how cars could be sold and serviced in Michigan.

Fortunately, the Senate never took up H.B. 6233, and it died with the expiration of the legislative session. Where that leaves things is exactly as they stood as of January 2020: Any EV company similarly situated to Tesla can, in principle, sell and service directly in Michigan, subject to the requirement of executing the sales transaction and titling out state and operating service centers through subsidiaries.

\footnotetext{
${ }^{10} \mathrm{https}: / /$ profdancrane.files.wordpress.com/2020/09/hb-6233-white-paper-.pdf.
} 


\section{Costs of Present Regulatory SCHEMe}

The regulatory status quo in Michigan is considerably better than in was before the January 2020 Tesla settlement, but it is far from optimal. As revealed in the last legislative session, the car dealers are continuing to push for legislative reforms that would blow up the Tesla settlement and destroy the opportunity for direct distribution in Michigan, codifying mid-twentieth century distribution practices for the twenty-first century. Moreover, even if the Tesla settlement remains intact, it does not seem to permit direct sales by legacy car companies like GM, Ford, and Chrysler, which could put them at a severe competitive disadvantage in the new world of EVs. Finally, by forcing the formal sales and titling transaction to occur outside of Michigan, the current structure threatens to lead to a significant economic losses to the State of Michigan.

\section{EV Market Penetration}

As noted earlier, EV companies have made a strong case that traditional dealer distribution is not viable for EVs. Adding to the set of reasons offered earlier by Tesla, Rivian testified at the H.B. 6233 hearings that direct sales and servicing are vital to EV companies whose business and technological model relies on a close and ongoing relationship with their customers. For example, Rivian will give its customers the option to have their vehicle's performance continuously monitored over-the-air by Rivian, with the company able to offer customers immediate feedback and assistance with respect to vehicle performance. That sort of relationship requires a direct and close relationship between the company and its customers. Similarly, much of the servicing for EVs will occur through over-the-air software updates, which again assumes a direct relationship between company and customer.

To be clear, no one is arguing that it is impossible to sell EVs through traditional dealers. At the hearings on H.B. 6233, several members of the Committee related that they had 
purchased an EV from a dealer. However, that a highly motivated customer may be able to purchase an EV from a franchised dealer does not mean that dealer distribution will be nearly as effective at advancing EV market penetration or providing customers with optimal sales and service experiences. To the contrary, there is empirical evidence that most dealers are not highly motivated to sell EVs. Consumer Reports sent secret shoppers to 85 dealerships that did stock some EVs. ${ }^{11}$ It found that 13 out of the 85 dealers actively discouraged customers from buying an $\mathrm{EV}$, and 35 more recommended buying an internal combustion car instead. The dealers seemed uniformed about EVs, had few in stock, and had few options or choices on the ones they had. "A sales manager at Manhattan Ford in New York City, the only Ford dealership actually owned by the automaker, at first denied there was a Focus EV, and then said it couldn't be leased. Both statements are incorrect." At another dealership, the dealer wouldn't even show the secret shopper an EV, even though they had one in stock. Given the economic disincentives dealers have to sell EVs (discussed above), none of this should be surprising. Recently, 150 Cadillac dealers accepted buy-outs instead of agreeing to start selling EVs. ${ }^{12}$

That the current franchised dealer model is ill-suited for EV sales does not mean that dealers cannot be effective players in the world of EV sales and service. However, for them to do so requires a fundamental change their business model. Some dealerships are wisely beginning to understand this and look for new ways to interact with car companies and their customers to provide value in the very different EV world. In that world, car distribution and service will look little like it did in 1950. Trying to lock EV distribution in the 1950s model will only serve to slow EV market penetration, to the disadvantage of Michigan's consumers and

\footnotetext{
${ }^{11} \mathrm{https}$ //www.consumerreports.org/cro/news/2014/04/dealers-not-always-plugged-in-about-electric-cars-secretshopper-study-reveals/index.htm

${ }^{12}$ https://www.cnbc.com/2020/12/04/about-150-cadillac-dealers-take-gm-buyouts-rather-than-invest-in-evs.html.
} 
society at large. It will also disadvantage American car companies trying to compete with EV manufacturers around the world - the sorts of distribution limitations at issue in the United States are not usually seen in the rest of the world.

\section{Environmental Impacts}

Slowing the market penetration of EVs also has undesirable environmental consequences. Internal combustion engine ears and trucks account of one-fifth of carbon emissions in the United States. The faster the transition to EVs, the faster the reduction in the automotive sector's contribution to carbon emission. For this reason, a coalition of environmental organizations, including the Sierra Club, Environmental Council, Electrification Coalition, Ecology Center, E2, Plugin America, and Cleanfuels Michigan are actively working to promote EV direct distribution. These organizations understand that laws restricting direct distribution are major impediments to more people driving EVs, and have therefore made removing these restrictions a policy priority.

\section{Consumer Choice and Consumer Protection}

Although the dealers' lobby has tried to advance a consumer protection rationale for direct distribution prohibitions, that argument has no support in the history of the dealer franchise laws or in economics. The direct distribution laws were passed to protect dealers, not consumers. Every consumer advocacy organization that has weighed in on the issue-including the staff of the Federal Trade Commission, Consumer Reports, Consumer Action, Consumers for Auto Reliability and Safety, and the American Antitrust Institute— has taken the position that bans 
on direct sales are bad for consumers and that direct sales should be allowed. ${ }^{13}$ Economists and academic experts on competition policy have uniformly taken the same position. ${ }^{14}$ There is no consumer protection reason to ban direct sales, and every reason to permit consumers to make up their own minds about how they buy their cars.

In the last legislative session, the dealers argued that preventing other companies from taking advantage of the Tesla settlement was necessary from a consumer protection perspective because, otherwise, vehicle sales would go "unregulated." What they apparently meant was that, since the sales transaction would occur outside of Michigan, the sales entity would not be a dealer licensed in Michigan and subject to Michigan consumer protection regulations. This argument is perverse. The only reason that the sales transaction has to be sent outside of Michigan is that the dealers themselves procured the 2014 legislative amendments that prevented Tesla from getting a Michigan dealer's license. While it's not true that the sale transaction is unregulated (the sales transaction is regulated in the state where it occurs), the EV companies would be very happy to get a Michigan dealer's license and be fully regulated in Michigan, just like any other dealer. The appropriate response to this fabricated problem of "unregulated sales" is not to ban direct sales, but to allow EV companies to get a dealer license - exactly what they are asking for.

\section{Threats to the Free Market}

The coalition of groups supporting a car company's right to sell and service its cars directly includes the strange bedfellows of environmental, consumer, and free market groups like

\footnotetext{
${ }^{13}$ https://www.autonews.com/assets/PDF/CA98362217.PDF; https://www.ftc.gov/system/files/documents/advocacy_documents/ftc-staff-comment-regarding-michigan-senatebill-268-which-would-create-limited-exception-current/150511 michiganautocycle.pdf.

${ }^{14}$ See, e.g., https://profdancrane.files.wordpress.com/2020/09/academics-letter-opposing-hb-6233-1.pdf
} 
the Mackinac Center, Americans for Prosperity, and Institute for Justice. ${ }^{15}$ Free market groups oppose direct sales bans on principle: why should the government tell a willing car company and a willing consumer that they cannot transact directly? Such bans may serve the dealers economic interests, but protecting some special interest group from competition is not a sound basis for law. Indeed, it is unconstitutional. ${ }^{16}$

5. Economic Impacts for the State of Michigan

\section{a. Lost Sales Tax Revenues}

The State of Michigan collects a $6 \%$ sales tax on vehicle sales. If a Michigan resident purchases a vehicle outside the State of Michigan and then brings it back to Michigan and registers it here, whether Michigan collects a sales tax — and in what amount — depends on whether the other state has a tax reciprocity agreement with Michigan. ${ }^{17}$ Where Michigan has a tax reciprocity agreement with another state, there is no loss of tax revenue to Michigan from out-ofstate purchase and titling by a resident, since the other state remits either the full $6 \%$ tax to Michigan, or, if it collects a lower sales tax amount, it remits the amount collected and Michigan collects the balance up to a total of $6 \%$ upon registration in Michigan. However, if the other state collects a sales tax on the sale and does not have a reciprocity agreement with Michigan, "credit is given for any sales or use tax that is legally due and paid in another state at the time of purchase." 18

\footnotetext{
15 https://www.autonews.com/assets/PDF/CA98362217.PDF.

${ }^{16}$ Craigmiles v. Giles, 312 F.3d 220, 229 ( $6^{\text {th }}$ Cir. 2002) (holding that a "measure to privilege certain businessmen over others at the expense of consumers is not animated by a legitimate governmental purpose and cannot survive even rational basis review").

$17 \mathrm{http}: / / \mathrm{msdra} . c 0 \mathrm{~m} / \mathrm{out}$ of_state_buyersales_tax.htm.

$18 \mathrm{https} / / /$ www.michigan.gov/taxes/0,4676,7-238-43519_43529-154427--,00.html.
} 
At present, a quarter of other states do not have reciprocity agreements with Michigan. This means that Michigan stands to lose significant vehicle sales tax revenues if Michigan residents are forced to buy and title EVs out of state. Annually, Michigan new vehicle sales taxes account for around $\$ 1$ billion, or about $10 \%$ of the State's tax revenues. ${ }^{19} \mathrm{EV}$ sales are bound to grow significantly as a share of the market in coming years. As a back-of-the-envelope exercise, consider the quickly approaching year in which out-of-state EV sales hit $20 \%$ of the market. If Michigan lost sales tax revenues in proportion to the number of states without reciprocity agreements, this would mean a loss of $25 \%$ of $\$ 200$ million, or $\$ 50$ million in tax revenues. At $40 \% \mathrm{EV}$ market penetration, the number would grow to $\$ 100$ million in lost tax revenues.

Those assumptions may be understated because they assume other states continue to maintain reciprocity agreements with Michigan. It is far from certain that they will if Michigan remains an outlier on direct sales. The instinct behind reciprocity agreements is that, on average, equal numbers of non-residents buy cars in the compacting states so that, on average, the reciprocity agreements are revenue-neutral. But, as EV sales grow, if Michigan maintains a prohibition on direct distribution, other states will find it to their advantage to encourage titling in their own state and associated collection of sales taxes. Unless Michigan updates its vehicles sales laws, it could soon find itself with significantly dwindling motor vehicle tax revenues and a serious hit to its sales tax revenue base. ${ }^{20}$

\footnotetext{
${ }^{19} \mathrm{https}$ ///autoalliance.org/in-your-state/MI/pdf/?export.

${ }^{20} \mathrm{It}$ is also possible that the current regulatory scheme would lead to a loss of corporate income tax revenue. Michigan collects a 6\% corporate income tax based on sales in Michigan. https://www.michigan.gov/taxes/0,4676,7238-43519_59553_69155-265028--,00.html. Sales of tangible personal property, such as cars, are deemed to occur in Michigan if the vehicle is shipped to or delivered to a customer in Michigan. MCL 208.1305(1)(a). Even though the party consummating the sale might be a different corporate entity than the Michigan subsidiary performing retail operations in Michigan, Michigan treats affiliated groups of taxpayers as a single business group, hence, in principle, a sale from a foreign corporation to a Michigan resident should count for income tax purposes as a sale in Michigan if the car is going to be delivered in Michigan. Nonetheless, the Attorney General's interpretation of
} 
b. Lost Franchise Fees, Property Taxes, Local Investment, and Employment

In addition to these lost sales tax revenues, by requiring car companies wishing to make direct EV sales to locate their sales facilities out of state, Michigan's regulatory scheme will reduce the physical presence of sales centers in Michigan and thereby deprive the state and local governments from collecting a variety of other taxes and fees such as franchise registration fees and property taxes. Prohibiting car companies from locating sales operations in Michigan will lead to a loss of local investment and jobs. A company selling EVs to Michigan residents would be forced to locate all of the operations supporting those transaction in another state. So, for example, an employee handling titling and financing for Michigan residents might be located in California rather than Michigan. That would represent the loss of a Michigan job and all that goes with it - the physical office space (real estate investments or leasing), local spending supporting that employee's activities, income taxes paid by the employee, and the economic and social benefits that come from bringing productive people to the State.

c. Negative Impact on Michigan's Reputation as an Automotive Innovation Hub A final factor is less tangible, but perhaps even more significant in the long run. For many years, Michigan has been fighting negative publicity and popular impressions about the Michigan car industry and to restore is reputation as the car capital of the world. Governor Whitmer has called for Michigan to play a leading role in bold and transformative thinking about automobiles and mobility technology. ${ }^{21}$ The Governor's Office of Future Mobility seeks to reaffirm "Michigan's position as the global leader in producing and developing the next-generation

\footnotetext{
Michigan law raises questions about how a sale outside of Michigan to a Michigan resident should be treated for interstate revenue allocation purposes. Given that Michigan law prohibits the sale to incur "in Michigan" for purposes of the dealer law, corporations might be successful in arguing that the sale does not incur "in Michigan" for purposes of the tax law either. If so, the result would be a significant loss of corporate tax revenue, in addition to the loss of sales tax revenue.

${ }^{21} \mathrm{https}$ ://www.michigan.gov/whitmer/0,9309,7-387-90487-498358--,00.html.
} 
of transportation technologies." 22 Among the State's goals are increasing mobility investment in Michigan, engaging more mobility startups, accelerating EV adoption in Michigan, and bolstering Michigan's mobility manufacturing core.

But, to put it mildly, maintaining a set of dated prohibitions on innovation in automobile distribution that are badly out of step with emerging standards around the country does not project a good image for Michigan. In 2014, the legislative reforms targeted at stopping Tesla from selling in the state was covered negatively in the media across the country and around the world. For example, the Wall Street Journal ran a national editorial condemning Michigan for technological backwardness ${ }^{23}$ and the Information Technology \& Innovation Foundation named Michigan one of four winners of its dreaded "Luddite Award."24

Already, a number of EV start-ups have made significant investments in Michigan, with Rivian's headquartering in Plymouth perhaps the most salient example. Attracting continuing investments by these and other companies requires projecting a positive environment for innovation in the way cars are designed, built, sold, and serviced. Restricting the right of a manufacturer to sell and service its vehicles in ways that meet its business needs sends exactly the wrong signal. American EV start-ups like Tesla, Rivian, Lordstown, Lucid, and Bollinger have made it clear that they view the right to transact directly with their customers as being critical to the success of their products. Michigan should be leading the way in fostering an environment in which car manufacturers can experiment with varied distribution and servicing models.

\footnotetext{
${ }^{22} \mathrm{https}$ //www.michigan.gov/whitmer/0,9309,7-387-90499_90640-533468--,00.html.

${ }^{23}$ Rick Snyder Drives off the Road: Michigan's Pro-Market Governor Embraces the Car Dealer Cartel, W ALL STREET J. (Oct. 24, 2014, 7:18 PM), www.wsj.com/articles/rick-snyder-drives-off-the-road-1414192688.

${ }^{24}$ Robert Sorokanich, Gov. Snyder's Anti-Tesla Law Wins Michigan the “Luddite Award”, CAR \& DRIVER (Jan. 8, 2015, 10:23 AM), http://blog.caranddriver.com/gov-snyders-anti-tesla-law-wins-michigan-the-luddite-award.
} 


\section{Potential Legislative Reforms}

If there's one thing that almost everyone on all sides of the issue agrees on, it's that the status quo on vehicle direct sales and service in Michigan is not optimal. It's time for the issue to be considered systematically, openly, and with input from all stakeholders. Legislative reform is needed, not just to slap a patch on the problem, but to the lay foundation for a fair, rational, and successful system of vehicle sales and service in the car industry's incipient technological and economic revolution.

For those favoring reforms to allow direct EV sales and service, there are two potential flavors of reform legislation:

- Model 1: Manufacturers selling only EVs licensed as dealers.

- Model 2: Any manufacturer selling EVs licensed as a dealer for purposes of EV sales and service.

Model 1, which is similar to legislation adopted in Colorado, would essentially codify the Tesla settlement by allowing EV start-ups to sell and service directly, with the important caveat that they would be licensed as dealers in Michigan, obviating the need to conduct the sales and titling transaction out of state, with all of the associated economic costs to Michigan. However, this model would not permit legacy companies like GM, Ford, and Chrysler to conduct direct sales and service.

Model 2 would allow the legacy companies to join the EV start-ups in selling and servicing EVs directly, even while maintaining dealer distribution for internal combustion vehicles. While there is no plausible dealer protection objection to Model 1 since it would not implicate any dealer in an existing franchise relationship, the dealers might have some standing to complain that allowing their franchising manufacturers to sell EVs directly would be unfair. Any 
such argument would be weak. The legacy companies have sold relatively few EVs to date, and the dealers could protect themselves contractually against egregious exploitation or find new ways to add value in a hybrid distribution system.

In my view, Model 2 is preferable to Model 1 because it would allow the legacy companies to compete on a level playing field with the EV start-ups. In 2014, when Tesla and the dealers negotiated the previously mentioned legislative deal allowing Tesla to open three stores in Ohio, GM wrote a letter to Governor Kasich complaining that allowing Tesla "would gain a distinct competitive advantage" from being able to sell direct. ${ }^{25}$ Unfortunately, GM's demand was to close the door to direct sales for Tesla, not to open it for GM. GM was right that direct sales represent a competitive advantage - this White Paper has argued that, for EV sales, it is not just an advantage, it is critical. The law should not pick winners and losers. Direct sales and service should be available for any company selling EVs.

\section{CONCLUSION}

Michigan has an opportunity to show its leadership on the future of car distribution and automotive technology by passing reform legislation that protects the car dealers' legitimate reliance interests in the distribution system for internal combustion vehicles, but also recognizes the very different demands of EV distribution. It's time to allow EV manufacturers and consumers to experiment with new distribution models that allow greater flexibility and freedom in how cars are bought and sold.

\footnotetext{
${ }^{25} \mathrm{https} / / /$ insideevs.com/photo/3934484/general-motors-sends-anti-tesla-direct-sales-letter-to-ohio-governor/.
} 